\title{
Identifikasi faktor penyebab dan upaya guru Geografi mengatasi rendahnya minat siswa pada kelas lintas minat Geografi SMA negeri di Kota Malang
}

\author{
Reinaldi Hasiholan Butarbutar, Hadi Soekamto*, Marhadi Slamet Kistiyanto \\ Universitas Negeri Malang, Jl. Semarang No. 5 Malang, Jawa Timur, Indonesia \\ *Penulis korespondensi, Surel: hadi.soekamto.fis@um.ac.id
}

Paper received: 02-03-2021; revised: 15-03-2021; accepted: 30-03-2021

\begin{abstract}
Abstrak
Penelitian ini bertujuan untuk mengetahui faktor penyebab dan upaya guru geografi mengatasi rendahnya minat siswa pada kelas lintas minat geografi SMA Negeri di Kota Malang. Penelitian ini merupakan penelitian deskriptif kuantitatif. Penelitian ini menggunakan angket dan pedoman wawancara sebagai instrumen penelitian. Populasi dalam penelitian ini berjumlah 3437 siswa dan 18 guru geografi. Penentuan jumlah sampel untuk angket menggunakan teknik Slovin. Hasil pengumpulan pertama berupa angket yang menunjukkan bahwa (1) Faktor rasa senang $(63,7 \%)(2)$ Faktor bakat $(64,3)$ (3) Faktor mata pelajaran (83\%). Hasil pengumpulan kedua berupa pedoman wawancara yang menunjukan bahwa terdapat empat upaya guru geografi mengatasi rendahnya minat siswa pada kelas lintas minat geografi. Keempat upaya tersebut yaitu: 1) Memiliki kedekatan dengan seluruh siswa (16,6) 2) Mengadakan fieldtrip (11,1) 3) Pembelajaran di Luar Ruangan $(11,1)$ 4) Penerapan Sistem Paket Lintas Minat $(11,1)$.
\end{abstract}

Kata kunci: penyebab; rendahnya minat siswa; kelas lintas minat

\section{Pendahuluan}

Perubahan Kurikulum Tingkat Satuan Pendidikan (KTSP) menjadi kurikulum 2013 dilakukan karena tiga alasan. Ketiga alasan tersebut yaitu KTSP tidak sesuai dengan tuntutan zaman, KTSP terlalu sarat materi, dan guru tidak mampu membuat kurikulum secara mandiri (Machali, 2014). Kurikulum 2013 memiliki suatu program.Struktur program kurikulum 2013 pada jenjang SMA dibagi menjadi tiga jurusan dan kelas lintas minat. Ketiga jurusan itu meliputi Matematika dan Ilmu Alam (MIA), Ilmu-Ilmu Sosial (IIS), serta Ilmu Bahasa dan Budaya (IBB), (Kemendikbud, 2013). Dalam kurikulum 2013 juga terdapat kelas lintas minat. Kelas lintas minat merupakan kelas yang dipilih oleh siswa untuk mengambil mata pelajaran yang diminati di luar jurusannya. Program lintas minat memberi peluang yang baik kepada siswa. Peluang tersebut yaitu siswa dapat mengambil mata pelajaran di luar jurusannya sesuai minat. Pernyataan ini sesuai dengan UU tentang Sistem Pendidikan Nasional Nomor 20 tahun 2003 pasal 12 ayat (1) butir (b) tentang Sistem Pendidikan Nasional bahwa "Siswa berhak mendapatkan pelayanan pendidikan sesuai dengan bakat, minat, dan kemampuannya."

Sebelum membahas pengertian minat siswa terhadap mata pelajaran geografi, maka perlu diketahui pengertian minat. Pengertian minat dikemukakan oleh beberapa para ahli. Para ahli tersebut terdiri dari Tampubolon, Djali, Mohamad Surya, dan Slameto. Menurut Tampubolon minat adalah perpaduan antara keinginan dan kemauan yang dapat berkembang melalui motivasi (Tampubolon, 1991). Sedangkan menurut Djali minat merupakan penerimaan akan sesuatu yang melibatkan hubungan antara dalam diri dengan luar diri siswa, sehingga sangat berpengaruh terhadap prestasi, karir maupun pekerjaan (Djali, 2008). Menurut Mohamad Surya minat dapat diartikan sebagai rasa senang atau tidak senang 
terhadap suatu objek (Surya, 2003). Pengertian minat yang dikemukakan oleh Mohamad Surya tersebut sejalan dengan pendapat Slameto, "Minat adalah rasa suka dan keterikatan terhadap suatu hal atau aktivitas, tanpa ada yang menyuruh" (Slameto, 2003). Berdasarkan beberapa pengertian di atas, maka dapat disimpulkan bahwa minat siswa terhadap mata pelajaran geografi berarti rasa suka, ketertarikan, keinginan, kemauan siswa untuk mendalami mata pelajaran geografi tanpa pengaruh dari orang lain.

Faktor yang mempengaruhi minat siswa juga dikemukakan oleh Syah. Menurut Syah, faktor yang mempengaruhi minat siswa terdiri dari tiga faktor. Ketiga faktor tersebut adalah (1) Faktor internal adalah faktor dari dalam diri siswa yang meliputi dua aspek. (a) Aspek fisiologis, (b) Aspek psikologis; (2) Faktor eksternal siswa terdiri dari dua macam, yaitu faktor lingkungan sosial dan faktor lingkungan nonsosial; (3) Faktor pendekatan belajar yaitu segala cara atau strategi yang digunakan siswa dalam menunjang keefektifan dan efisiensi proses mempelajari materi tertentu. (Syah, 2010). Sedangkan menurut Slameto (2010) faktor penyebab minat siswa yang rendah yaitu (1) Faktor internal terdiri dari: (a) Faktor jasmani, (b) Faktor psikologis, (c) Faktor kelelahan; (2) Faktor eksternal terdiri dari: (a) Faktor keluarga, (b) Faktor sekolah, (c) Faktor masyarakat.

Sebelum membahas upaya guru geografi dalam mengatasi rendahnya minat siswa pada kelas lintas minat geografi, maka perlu dipahami pengertian upaya dan guru. Upaya menurut kamus besar bahasa Indonesia KBBI (2002), diartikan sebagai usaha kegiatan yang mengarahkan tenaga, pikiran untuk mencapai suatu tujuan. Pengertian tersebut sejalan dengan yang diungkapan oleh Peter Salim dan Yeni Salim, upaya adalah bagian yang dimainkan oleh orang atau bagian dari tugas utama yang harus dilakukan. (Salim, 2002). Berdasarkan dua pernyataan tersebut dapat disimpulkan bahwa upaya adalah kegiatan yang dilakukan seseorang guna memperoleh perubahan yang lebih baik.

Pengambilan kelas lintas minat geografi SMA Negeri di Kota Malang juga tergolong rendah. Hal ini dibuktikan dari data tabel di bawah bahwa minat siswa dalam mengambil kelas lintas minat mata pelajaran geografi SMA Negeri di Kota Malang tergolong rendah. Hal ini dibuktikan dengan rata-rata persentase siswa yang mengambil kelas lintas minat mata pelajaran geografi hanya $29,3 \%$.

\section{Metode}

Penelitian ini tergolong dalam jenis penelitian deskriptif kuantitatif. Penelitian ini bertujuan untuk mendeskripsikan secara menyeluruh dan faktual mengenai gejala, peristiwa, dan kejadian saat ini. Penelitian ini tidak mengubah, menambah, bahkan tidak memanipulasi data terhadap objek maupun wilayah yang diteliti. Jumlah populasi dalam penelitian ini adalah seluruh siswa yang tidak mengambil kelas lintas minat mata pelajaran geografi yang berjumlah 3.447 siswa. Sedangkan jumlah guru geografi di SMA Negeri Kota Malang yang terdiri dari guru PNS dan GGT berjumlah 20. Teknik pengambilan sampel pada penelitian ini menggunakan proportional sampling yaitu cara pengambilan sampel dari setiap sub populasi dengan memperhitungkan besar kecilnya sub-sub populasi tersebut, sehingga dapat diketahui sampel dari penelitian ini adalah 358 siswa dan 18 guru geografi. Instrumen dalam peneitian ini menggunakan angket, jumlah pertanyaan dalam angket terdapat 19 butir. Teknik analasis data dalam penelitian ini menggunakan skor dan tabulasi. 


\section{Hasil dan Pembahasan}

Faktor penyebab minat siswa yang rendah dalam mengambil kelas lintas minat mata pelajaran geografi pada kota Malang 3 faktor yang menjadi penyebab. Ketiga faktor tersebut adalah (1) Faktor rasa senang, (2) Faktor bakat, (3) Faktor mata pelajaran. Faktor tersebut dikategorikan sebagai faktor penyebab minat siswa apabila hasil persentase $>61 \%$ dan faktor yang dikategorikan tidak menjadi penyebab apabila hasil persentase $<61 \%$. Hal ini dapat dibuktikan pada tabel dibawah ini.

Tabel 1. Mengambil Kelas Lintas Minat Mata Pelajaran Geografi

\begin{tabular}{lll}
\hline Klasifikasi & Persentase (\%) & Faktor Penyebab \\
\hline Rasa Senang & 63,7 & Penyebab \\
Bakat & 64,3 & Penyebab \\
Kemampuan & 33,2 & Tidak Penyebab \\
Keluarga & 22,1 & Tidak Penyebab \\
Mata Pelajaran & 83 & Penyebab \\
Lingkungan & 7,6 & Tidak Penyebab \\
\hline
\end{tabular}

Dari hasil wawancara yang telah dilakukan dengan 18 guru di SMA Negeri se-Kota Malang memiliki jawaban yang beragam. Hasil penelitian menunjukan $(11,1 \%)$ guru mengadakan fieldtrip sebagai upaya untuk mengatasi rendahnya minat siswa dalam mengambil kelas lintas minat mata pelajaran geografi. Hasil lainnya menunjukan $(16,6 \%)$ guru mendekatkan diri pada seluruh siswa MIPA, IBB, dan juga IIS sebagai upaya untuk mengatasi rendahnya minat siswa dalam mengambil kelas lintas minat mata pelajaran geografi. Hasil lainnya juga menunjukan $(11,1 \%)$ untuk guru yang mengadakan pembelajaran di luar ruangan dan $(11,1 \%)$ untuk guru yang menerapkan paket sistem lintas minat sebagai upaya untuk mengatasi rendahnya minat siswa dalam mengambil kelas lintas minat mata pelajaran geografi. Separuhnya (50\%) guru tidak memiliki upaya sama sekali untuk mengatasi rendahnya minat siswa dalam mengambil kelas lintas minat mata pelajaran geografi.

Berdasarkan pendapat Syah, Slameto, Subekti, dan penelitian sebelumnya faktor penyebab minat siswa yang rendah dalam mengambil kelas lintas minat mata pelajaran geografi terdiri dari enam faktor. Keenam faktor tersebut yaitu (1) Faktor rasa senang siswa, (2) Faktor bakat, (3) Faktor kemampuan, (4) Faktor keluarga, (5) Faktor mata pelajaran, (6) Faktor lingkungan. Tetapi dalam penelitian ini terdapat tiga faktor penyebab minat siswa yang rendah dalam menagambil kelas lintas minat mata pelajaran geografi SMA Negeri di Kota Malang. Ketiga faktor tersebut yaitu faktor rasa senang, bakat, dan faktor mata pelajaran.

Rasa senang merupakan faktor yang timbul dari dalam diri siswa. Rasa senang ini muncul karena adanya kepuasaan diri, rasa lega, terhindar dari susah, rumit, dan kecewa, serta memiliki rasa bahagia sehingga dapat menimbulkan rasa suka yang akan berdampak pada minat siswa untuk mendalami materi pelajaran. Faktor rasa senang merupakan salah satu faktor yang menyebabkan rendahnya minat siswa dalam mengambil kelas lintas minat geografi. Hal ini sejalan dengan pendapat Subekti (2007) yang mengungkapkan bahwa "Faktor dari dalam (intrinsik) yaitu berarti bahwa sesuatu perbuatan memang diinginkan karena seseorang senang melakukannya. Minat datang dari dalam diri orang itu sendiri. Orang senang melakukan perbuatan itu demi perbuatan itu sendiri. Seperti: rasa senang, mempunyai perhatian lebih, semangat, motivasi, emosi." Berdasarkan pernyataan tersebut mengungkapkan bahwa rasa senang termasuk dalam salah satu faktor dari dalam yang 
memengaruhi minat siswa, sehingga dapat diartikan bahwa rasa senang merupakan salah satu faktor penyebab minat siswa yang rendah dalam mengambil kelas lintas minat mata pelajaran geografi.

Berdasarkan data hasil penelitian faktor rasa senang merupakan salah satu faktor yang menyebabkan rendahnya minat siswa dalam mengambil kelas lintas minat geografi. Hal ini dikarenakan siswa sudah memikirkan dan sudah mendapat gambaran tentang masa depannya, sehingga siswa tersebut cenderung mengikuti mata pelajaran yang disenanginya. Sejalan dengan pendapat Djamarah (2002) indikator minat belajar yaitu rasa suka/senang, pernyataan lebih menyukai, adanya rasa ketertarikan adanya kesadaran untuk belajar tanpa di suruh, berpartisipasi dalam aktivitas belajar, memberikan perhatian." Berdasarkan pernyataan tersebut siswa yang memiliki perasaan senang terhadap pelajaran tertentu maka tidak akan ada paksaan untuk belajar. Selain itu, hasil angket menunjukan bahwa siswa di kota Malang lebih menyukai mata pelajaran selain geografi. Hal ini dikarenakan kota Malang identik dengan kota pendidikan dan mimiliki beberapa kampus ternama di Indonesia, sehingga pemikiran siswa cenderung sudah memikirkan cita-cita yang akan dicapai dan mendalaminya saat siswa tersebut berada di bangku SMA.

Faktor kedua yang memengaruhi penyebab minat siswa yang rendah dalam mengambil kelas lintas minat mata pelajaran geografi adalah faktor bakat. Hal ini sejalan dengan pendapat Syah (2010) yang mengungkapkan bahwa "Faktor internal adalah faktor dari dalam diri siswa yang meliputi dua aspek. (a) aspek fisiologis kondisi jasmani dan tegangan otot (tonus) yang menandai tingkat kebugaran tubuh siswa, hal ini dapat mempengaruhi semangat dan intensitas siswa dalam pembelajaran. (b) aspek psikologis aspek psikologis merupakan aspek dari dalam diri siswa yang terdiri dari, intelegensi, bakat siswa, sikap siswa, minat siswa, motivasi siswa." Faktor bakat merupakan faktor penyebab minat siswa yang rendah dalam mengambil kelas lintas minat geografi. Lebih dari separuh siswa di kota Malang memiliki bakat terhadap mata pelajaran geografi yang rendah dan lebih memilih mengembangkan bakat lain. Bakat merupakan salah satu faktor penyebab minat siswa karena antara bakat dan minat memiliki satu kesatuan. Hal ini sejalan dengan pendapat Sujanto (2004) mengungkapkan bahwa minat adalah perbuatan perhatian yang sengaja terlahir dengan kemauan dan bergabung pada minat dan bakat. Sehingga bakat merupakan salah satu faktor penyebab minat siswa karena minat dan bakat merupakan satu kesatuan.

Faktor ketiga mengenai faktor penyebab minat siswa yang rendah dalam mengambil kelas lintas minat mata pelajaran geografi adalah faktor mata pelajaran. Hasil penelitian ini sejalan dengan pendapat Syah dan sejalan dengan penelitian sebelumnya yang dilakukan oleh Budiyarti. Syah mengungkapkan bahwa "Faktor eksternal siswa terdiri dari dua macam, yaitu faktor lingkungan sosial dan faktor lingkungan nonsosial. (a) Lingkungan Sosial, lingkungan sosial terdiri dari sekolah, keluarga, masyarakat dan teman sekelas (b) Lingkungan Nonsosial, lingkungan sosial terdiri dari gedung sekolah dan letaknya, faktor materi pelajaran, waktu belajar, keadaan rumah tempat tinggal, alat-alat belajar." (Syah, 2010).

Faktor mata pelajaran merupakan faktor dengan persentase tertinggi dibandingkan kedua faktor sebelumnya yaitu rasa senang dan bakat. Hal ini berarti mata pelajaran merupakan faktor penyebab minat siswa yang mendominasi di SMA Negeri Kota Malang. Hal ini dibuktikan dengan jawaban siswa dalam pengisian angket, sebagian besar siswa tidak memilih kelas lintas minat mata pelajaran geografi karena mata pelajaran geografi sulit, materi 
yang diajarkan terlalu banyak, dan materi dalam mata pelajaran geografi terdapat hitung menghitung. Sehingga siswa tidak mengambil kelas lintas minat mata pelajaran geografi karena sulit.

Berdasarkan hasil dari penelitian yang telah dilakukan, selain faktor rasa senang, faktor bakat, dan faktor mata pelajaran yang dapat memengaruhi penyebab minat siswa yang rendah dalam mengambil kelas lintas minat mata pelajaran geografi, ada pula faktor yang tidak memengaruhi penyebab minat siswa yang rendah dalam mengambil kelas lintas minat mata pelajaran geografi. Faktor tersebut adalah faktor kemampuan, faktor keluarga, dan faktor lingkungan. Menurut hasil angket yang telah disebarkan kepada siswa, menunjukkan bahwa hanya sebagian kecil siswa memilih ketiga faktor tersebut.

Upaya guru geografi mengatasi rendahnya minat siswa pada kelas lintas minat geografi SMA Negeri di Kota Malang beraneka-ragam, namun tidak sedikit juga guru yang tidak melakukan upaya apapun. $50 \%$ guru melakukan upaya mengatasi rendahnya minat siswa pada kelas lintas minat geografi dan 50\% lagi guru tidak melakukan upaya. Upaya guru untuk mengatasi rendahnya minat siswa dalam mengambil kelas lintas minat mata pelajaran geografi bervariasi. Upaya yang pertama dengan mengadakan fieldtrip ke kota Batu. Metode fieldtrip ialah cara mengajar yang dilaksanakan dengan mengajak siswa ke suatu tempat atau obyek tertentu di luar sekolah. Upaya yang kedua ialah guru memiliki kedekatan dengan seluruh siswa baik MIPA ataupun IBB. Hubungan ini akan mampu menghilangkan dinding pembatas antara pendidik dan terdidik. Hal ini akan semakin mendekatkan perbedaan yang ada di antara pendidik dan anak didik. Hal ini sejalan dengan pendapat Sardiman (2004) yang mengungkapkan hubungan guru dan siswa didalam proses belajar mengajar merupakan faktor yang sangat menentukan. Upaya ketiga yang dilakukan guru untuk mengatasi rendahnya minat siswa pada kelas lintas minat geografi adalah mengadakan pembelajaran luar ruangan kelas. Hal ini dilakukan untuk mengatasi rasa bosan atau jenuh siswa selama mengikuti proses pembelajaran. Sejalan dengan pendapat Paisley (2008) yang mengatakan pengalaman yang didapatkan siswa dari hasil pembelajaran di luar ruangan kelas akan berdampak lebih panjang pada siswa, karena dengan mengamati, mendengar dan merasakan secara langsung fenomena yang terjadi di lingkungan meningkatkan ketertarikan siswa terhadap pembelajaran. Upaya terakhir yang dilakukan guru ialah menerapkan sistem paket lintas minat. Guru dan sekolah bekerja sama dalam melakukan sistem paket lintas minat. Paket lintas minat yaitu siswa kelas satu dapat memilih kelas lintas minat sebanyak dua kelas dan di kelas dua siswa diwajibkan memilih satu kelas lintas minat saja. Hal ini berhasil dalam mengatasi rendahnya minat siswa dalam mengambil kelas lintas minat. Dan separuh lagi (50\%) guru tidak melakukan upaya apapun untuk mengatasi rendahnya minat siswa dalam mengambil kelas lintas minat geografi.

Berdasarkan hasil penelitian yang telah dilakukan mengenai faktor penyebab dan upaya guru geografi mengatasi rendahnya minat siswa pada kelas lintas minat mata pelajaran geografi SMA Negeri di Kota Malang terdapat tiga faktor yang menjadi penyebab minat siswa yang rendah dalam mengambil kelas lintas minat mata pelajaran geografi dan terdapat empat upaya yang dilakukan guru untuk mengatasi rendahnya minat siswa pada kelas lintas minat geografi. 


\section{Simpulan}

Berdasarkan tujuan dan hasil penelitian yang telah dilakukan, maka dapat disimpulkan bahwa minat siswa yang rendah dalam mengambil kelas lintas minat mata pelajaran geografi SMA Negeri di Kota Malang disebabkan oleh faktor rasa senang, bakat, dan faktor mata pelajaran. Upaya guru untuk mengatasi rendahnya minat siswa dalam mengambil kelas lintas minat mata pelajaran geografi dengan mengadakan fieldtrip, serta melakukan pembelajaran di luar ruangan, menerapkan sistem paket lintas minat, dan memiliki kedekatan dengan seluruh siswa MIPA, IBB, dan IIS.

\section{Daftar Rujukan}

Akbar, S. D. (2013). Instrumen perangkat pembelajaran. Bandung: PT Remaja Rosdakarya.

Bashori, B. (2016). Manajemen Perubahan Kurikulum KTSP 2006 Ke-Kurikulum 2013 Di SMA Negeri 1 Kediri. Jurnal Penelitian LPPM (Lembaga Penelitian dan Pengabdian kepada Masyarakat) IKIP PGRI Madiun, 4(2), 94-106.

Darmawan, T. (2007). Minat dan Bakat Anak. Jakarta: Gramedia

Data Pokok Pendidikan. (2017). Data Pokok Pendidikan Kota Malang. Malang: Dinas Pendidikan Kota Malang.

Kande, F. A. (2008). Membedah Kekuatan dan Kelemahan KTSP (Antara Globalisasi Lokal dan Ancaman Disintegrasi Bangsa). Jurnal Manajemen Pendidikan UNY, 4(2): 79-89.

Killis, J. (1988). Hubungan minat kerja, motivasi ekstrinsik dan bimbingan dalam pelajaran dengan kecakapan kerja teknik listrik lulusan STM pada industri-industri DIY. Jakarta: Fakultas Pasca Sarjana IKIP.

Lutfiyah, Z., Utaya, S., \& Susilo, S. (2016). Hubungan antara Minat Menjadi Guru dengan Prestasi Belajar Mahasiswa. Jurnal Pendidikan Geografi: Kajian, Teori, dan Praktek dalam Bidang Pendidikan dan Ilmu Geografi, 21(2).

Machali, I. (2014). Kebijakan perubahan kurikulum 2013 dalam menyongsong Indonesia emas tahun 2045. Jurnal Pendidikan Islam, 3(1), 71-94.

Meyzilia, A., Darsiharjo, D., \& Ruhimat, M. (2019). Minat belajar geografi siswa SMA Negeri Se-Kabupaten Bangka. Jurnal Pendidikan Geografi: Kajian, Teori, dan Praktek dalam Bidang Pendidikan dan Ilmu Geografi, 24(1), 25-33.

Muhibbin, S. (2010). Psikologi Pendidikan dengan pendekatan baru. Bandung: PT Remaja Rosdakarya.

Mulyasa, E. (2013). Standar Kompetensi dan Sertifikasi Guru. Bandung: PT.Remaja Rosdakarya.

Mulyasa, E. (2014). Pengembangan dan Implementasi Kurikulum 2013. Bandung: PT. Remaja Rosdakarya.

Pendidikan, P. M., \& Nomor, K. (64). (2014). Tentang Peminatan Pada Pendidikan Menengah. Jakarta: Depdiknas.

Indonesia, P. R. (2013). Peraturan Menteri Pendidikan Pendidikan dan Kebudayaan Republik Indonesia Nomor 70 Tahun 2013 Tentang Kerangka Dasar dan Struktur Kurikulum Sekolah Menengah Kejuruan/Madrasah Aliyah Kejuruan. Madrasah Aliyah Kejuruan.

Peraturan Menteri Pendidikan dan Kebudayaan Republik Indonesia Nomor 81A Tahun 2013 tentang Implementasi Kurikulum.

Prastowo, A. (2014). Paradigma baru madrasah dalam implementasi kebijakan kurikulum 2013. Jurnal Pendidikan Islam, 3(1), 95-113.

Putri, D. T. N., \& Isnani, G. (2015). Pengaruh minat dan motivasi terhadap hasil belajar pada mata pelajaran pengantar administrasi perkantoran. JPBM (Jurnal Pendidikan Bisnis dan Manajemen), 1(2), 118-124. 